\title{
Bioaccumulation of organohalogenated compounds in sharks and rays from the southeastern USA
}

\author{
Liesbeth Weijs $^{\text {a,b,c,*, Nathalie Briels }}{ }^{\text {a,b,d }}$, Douglas H. Adams ${ }^{e}$, Gilles Lepoint ${ }^{\mathrm{f}}$, Krishna Das ${ }^{\mathrm{f}}$, \\ Ronny Blust ${ }^{\mathrm{a}}$, Adrian Covaci ${ }^{\mathrm{b}}$ \\ a Department of Biology, University of Antwerp, Groenenborgerlaan 171, 2020 Antwerp, Belgium \\ ${ }^{\mathrm{b}}$ Toxicological Centre, University of Antwerp, Universiteitsplein 1, 2610 Wilrijk, Belgium \\ ' National Research Centre for Environmental Toxicology (Entox), The University of Queensland, 39 Kessels Road, Coopers Plains, QLD 4108, Australia \\ d Norwegian University of Science and Technology (NTNU), Department of Biology, Høgskoleringen 5, Realfagbygget, 7491 Trondheim, Norway \\ e Florida Fish E' Wildlife Conservation Commission, Fish E Wildlife Research Institute, 1220 Prospect Ave., \#285, Melbourne, FL 32901, USA \\ ${ }^{\mathrm{f}}$ Laboratory for Oceanology-MARE Center, University of Liège B6C, 4000 Liège, Belgium
}

\section{A R T I C L E I N F O}

Article history:

Received 19 September 2014

Received in revised form

15 December 2014

Accepted 26 December 2014

Keywords:

PCBs

PBDES

DDXs

$\mathrm{HCB}$

MeO-PBDEs

CHLS

Bonnethead

Atlantic stingray

Lemon shark

Bull shark

\begin{abstract}
A B S T R A C T
Organohalogenated compounds are widespread in the marine environment and can be a serious threat to organisms in all levels of aquatic food webs, including elasmobranch species. Information about the concentrations of POPs (persistent organic pollutants) and of MeO-PBDEs (methoxylated polybrominated diphenyl ethers) in elasmobranchs is scarce and potential toxic effects are poorly understood. The aims of the present study were therefore to investigate the occurrence of multiple POP classes (PCBs, PBDEs, DDXs, HCB, CHLs) and of MeO-PBDEs in various elasmobranch species from different trophic levels in estuarine and marine waters of the southeastern United States. Overall, levels and patterns of PCBs, PBDEs, DDXs, HCB, CHLs and of MeO-PBDEs varied according to the species, maturity stage, gender and habitat type. The lowest levels of POPs were found in Atlantic stingrays and the highest levels were found in bull sharks. As both species are respectively near the bottom and at top of the trophic web, with juvenile bull sharks frequently feeding on Atlantic stingrays, these findings further suggest a bioaccumulation and biomagnification process with trophic position. MeO-PBDEs were not detected in Atlantic stingrays, but were found in all shark species. HCB was not found in Atlantic stingrays, bonnetheads or lemon sharks, but was detected in the majority of bull sharks examined. Comparison with previous studies suggests that Atlantic stingrays may be experiencing toxic effects of PCBs and DDXs on their immune system. However, the effect of these compounds on the health of shark species remains unclear.
\end{abstract} (c) 2014 Elsevier Inc. All rights reserved.

\section{Introduction}

Persistent organic pollutants (POPs) can bioaccumulate and biomagnify through food webs, and are of particular concern for top predators that typically contain the highest concentrations (Ross, 2000; Kelly et al., 2007). Top predators within marine environments typically include marine mammal and shark species. Numerous studies have found elevated levels of POPs in the tissues of marine mammals, as well as adverse effects that can be linked to those POP levels. Indeed, it has been shown in top predator species, such as harbor seals (Phoca vitulina), bottlenose dolphins (Tursiops truncatus) and polar bears (Ursus maritimus), that pollutants can reach high concentrations with negative effects on

\footnotetext{
* Corresponding author at: National Research Centre for Environmental Toxicology (Entox), The University of Queensland, 39 Kessels Road, Coopers Plains, QLD 4108, Australia.

E-mail addresses: liesbeth.weijs@uantwerpen.be, l.weijs@uq.edu.au (L. Weijs).
}

reproductive, immune and endocrine systems (Ross et al., 1996; Sonne et al., 2009; Schwacke et al., 2012). Marine mammals accumulate pollutants primarily via uptake through their diet and this may also be true for sharks. Shark species, however, may have a minor additional pathway for uptake, as there is also a substantial water flow and subsequent potential chemical uptake via gill respiration.

Toxicological studies are available for teleost fish and, to a lesser extent, also for sharks. Effect studies have been performed in several fish species like Atlantic salmon (Salmo salar), European flounder (Platichthys flesus) or Japanese medaka (Oryzias latipes) in the wild as well as in the lab (Nirmala et al., 1999; Vigano et al., 2001; Muirhead et al., 2006; Lerner et al., 2007; Nakayama and Oshima, 2008). Effects studies on sharks typically focus on smaller shark species, such as the spiny dogfish (Squalus acanthias, De Boeck et al., 2001; Eyckmans et al., 2013), since many larger shark species are difficult to maintain in captivity in adequate numbers and can be protected by conservation regulations. POP monitoring 
studies are frequently conducted on teleost fish, but are relatively scarce for sharks (Schlenk et al., 2005; Gelsleichter et al., 2005 and 2008; De Azevedo e Silva et al., 2009).

Chondrichthyan fishes (i.e. sharks, rays, skates, sawfishes and chimaeras) are an evolutionarily conservative group with diverse life histories and complex reproductive strategies. We examined one species of ray (Atlantic stingray - Dasyatis sabina) and three shark species (bonnethead - Sphyrna tiburo; lemon shark - Negaprion brevirostris; bull shark - Carcharhinus leucas).

Atlantic stingrays are a common benthic species in coastal waters of the southeastern USA, including the Gulf of Mexico, which occupies a wide range of habitats (freshwater, estuarine, or marine) and prefers depths less than $25 \mathrm{~m}$ (Funicelli, 1975; Johnson and Snelson, 1996). They prey upon small benthic crustaceans, polychaetes, echinoderms, and to a lesser extent, small fishes (Cook, 1994; Kajiura and Tricas, 1996). Atlantic stingrays are an aplacental viviparous species where embryos rely primarily on yolk for the first period of development, after which they survive on histotroph or uterine milk enriched with proteins and lipids (Snelson et al., 1988; Bone and Moore, 2008).

Bonnetheads are an abundant coastal shark species in estuarine and marine waters of the southeastern U.S. This hammerhead shark species is a dietary specialist that feeds principally on crustaceans, with crabs being a dominant prey, along with lesser amounts of mollusks and small fishes (Cortés et al., 1996; Lessa and Almeida, 1998; Bethea et al., 2007; Olin et al., 2013). The reproductive mode of bonnetheads is placental viviparity, and many estuarine and shallow nearshore waters of the southeastern USA serve as nursery grounds for this species (Heupel et al., 2006; Bethea et al., 2006).

Lemon sharks typically reside in shallow estuarine or nearshore coastal habitats as small juveniles (Reyier et al., 2008), but move to more open ocean waters at maturity (Morrissey and Gruber, 1993). Juvenile lemon sharks typically feed on a wide array of teleost fishes, with lesser amounts of crustaceans, elasmobranchs, and mollusks (Cortés and Gruber, 1990; Reyier et al., 2008). Lemon sharks are a placental viviparous species with direct transfer of nutrients from pregnant females to embryos through a yolk-sac placenta (Feldheim et al., 2002). This species is currently classified as 'near threatened' on the IUCN Red List, and are fully protected within Florida waters (FWC, 2014).

Bull sharks are one of the few completely euryhaline shark species, inhabiting estuarine and freshwater rivers throughout its range (Thorson, 1971; Thomerson et al., 1997). Shallow estuarine areas serve as nursery grounds for small juveniles, after which they move to coastal ocean waters as they begin to mature (Curtis et al., 2011). Adults have been found to migrate over fairly long distances (Carlson et al., 2010; Tillett et al., 2012). These sharks are opportunistic predators with a large variation in their diet spanning from teleost fishes to elasmobranchs, seabirds and marine mammals. As juveniles, they typically feed on small teleost fishes, Atlantic stingrays and lesser amounts of crustaceans (Snelson et al., 1984; Adams, unpublished data).

All species investigated in the present study were collected from estuarine waters of Indian River Lagoon (IRL) system on the Atlantic coast of Florida or adjacent nearshore waters of the Atlantic Ocean. The IRL is a shallow, estuarine system that occupies approximately one-third of Florida's central Atlantic coast and is considered one of the most diverse estuaries in North America. The IRL is a critical nursery ground for bull sharks (Curtis et al., 2011). Nearshore waters of the adjacent Atlantic Ocean in the area near Cape Canaveral, FL are critical nursery areas for many shark species including bonnetheads and lemon sharks (Adams and Paperno, 2007; Reyier et al., 2008). The IRL region has been suffering from long-term, large-scale mortality events across multiple species such as the Florida manatee (Trichechus manatus latirostris), bottlenose dolphin (Tursiops truncatus) and brown pelican (Pelecanus occidentalis) in recent years. Considering the known negative effects of POPs on marine mammals and teleost fish, it is important to better understand the concentrations of POPs in elasmobranch species that serve as key predators in many aquatic ecosystems. As such, the goal of the present study was to investigate the occurrence and patterns of POPs in sharks and rays from coastal waters of the southeastern USA.

\section{Materials and methods}

\subsection{Samples}

A total of 53 liver samples were analyzed for POPs and MeOPBDEs (methoxylated polybrominated diphenyl ethers), which are organohalogenated compounds with a potentially natural origin (Haraguchi et al., 2009). These samples were from 4 different species (Atlantic stingray - Dasyatis sabina; bonnethead shark Sphyrna tiburo; lemon shark - Negaprion brevirostris; bull shark Carcharhinus leucas; Table 1). For two species (Atlantic stingray and bonnethead), stable isotopes $\left(\delta^{13} \mathrm{C}\right.$ and $\left.\delta^{15} \mathrm{~N}\right)$ in muscle samples were also analyzed (15 samples in total; Table 1 ) from the same animals as included in the POP analyzes giving matched liver and muscle samples. All fish were collected from estuarine waters of Indian River Lagoon (IRL) system on the Atlantic coast of Florida or from adjacent nearshore waters of the Atlantic Ocean from north of Cape Canaveral, Florida (latitude $28^{\circ} 40^{\prime} \mathrm{N}$ ) south to Sebastian Inlet, Florida (latitude $27^{\circ} 50^{\prime} \mathrm{N}$ ) during 2009 to 2012 . For the POP analysis, 38 PCB (polychlorinated biphenyls) congeners, 6 PBDEs (polybrominated diphenyl ethers), 6 DDXs (dichlorodiphenyltrichloroethane and metabolites and isomers), HCB (hexachlorobenzene), 5 chlordanes (CHLs) and $4 \mathrm{MeO}$-PBDEs were targeted in all liver samples (Table S2).

\subsection{Sample preparation and POP analysis}

Approximately $0.2 \mathrm{~g}$ of liver was spiked with internal standards BDE 77 and CB 143 and extracted by hot Soxhlet for $2 \mathrm{~h}$ with hexane/acetone $(3 / 1 ; \mathrm{v} / \mathrm{v})$. After lipid determination performed on an aliquot of the extract (typically $1 / 8$ th), the extract was cleaned on $8 \mathrm{~g}$ of acidified silica and analytes were eluted with $20 \mathrm{ml}$ hexane and $15 \mathrm{ml}$ dichloromethane. The cleaned extract was evaporated to dryness and reconstituted in $150 \mu$ iso-octane. Details of the analytical methods are given in Weijs et al. (2009) and are briefly given here. PBDEs, MeO-PBDEs and CHLs were measured by GC-ECNI/MS (gas chromatography-electron capture negative ion/mass spectrometry) on a $30 \mathrm{~m} \times 0.25 \mathrm{~mm} \times 0.25 \mu \mathrm{m}$ DB-5 column by monitoring ions $m / z=79$ and 81 (for PBDEs and MeO-PBDEs) and 2 specific ions for each CHL. PCBs and DDXs were measured by GC-EI/MS (gas chromatography-electron ionization/ mass spectrometry) on a $25 \mathrm{~m} \times 0.22 \mathrm{~mm} \times 0.25 \mu \mathrm{m}$ HT- 8 column by monitoring 2 ions for each homolog group. This system was also used to confirm MeO-PBDEs.

Table 1

Overview of the number of samples of all species analyzed in this study. Gray indicates muscle tissue, white indicates liver tissue. Atlantic stingray - Dasyatis sabina; bonnethead - Sphyrna tiburo; bull shark - Carcharhinus leucas; lemon shark Negaprion brevirostris.

\begin{tabular}{lllll}
\hline & $\begin{array}{l}\text { Atlantic } \\
\text { stingray }\end{array}$ & Bonnethead & $\begin{array}{l}\text { Lemon } \\
\text { shark }\end{array}$ & Bull shark \\
\hline $\begin{array}{l}\text { Trophic transfer (TT) } \\
\text { Stable isotopes (SI) }\end{array}$ & 14 & 19 & 12 & 8 \\
\hline
\end{tabular}




\subsection{Quality assurance/quality control (QA/QC)}

Recoveries for individual PCB and PBDE congeners and RSD are given in Table S1. For each analyte, the mean procedural blank value was used for subtraction. After blank subtraction, the limit of quantification (LOQ) was set at $3 \times \mathrm{SD}$ of the procedural blank. For analytes that were not detected in procedural blanks, LOQs were calculated for a ratio $S / N$ equal to 10 . LOQs depended on the sample intake and on the analyte and ranged between 1 and $4 \mathrm{ng} /$ g lipid weight (lw). QC was performed by regular analyzes of procedural blanks, by random injection of standards and solvent blanks. A standard reference material SRM 1945 (PCBs, OCPs and PBDEs in whale blubber) was used to test the method accuracy. Obtained values did not deviate more than $10 \%$ from the certified values.

\subsection{Stable isotopes}

Measurements of $\delta^{13} \mathrm{C}$ and $\delta^{15} \mathrm{~N}$ in muscle samples of Atlantic stingrays and bonnethead sharks (Table 1) were used to investigate the trophic position. Briefly, after freeze drying $(48 \mathrm{~h})$, muscle samples were ground into a homogeneous powder of which $1.5 \mathrm{mg}$ was used. Samples were analyzed on a VG Optima (Micromass of IsoPrime100) IR-MS coupled to an N-C-S elemental analyzer (Carlo Erba) for automated analyzes. Routine measurements are precise to $0.3 \%$ for both ${ }^{13} \mathrm{C}$ and ${ }^{15} \mathrm{~N}$. Stable isotope ratios were expressed in $\delta$ notation according to the following equation:

$\delta X=\left[\left(R_{\text {sample }}-R_{\text {standard }}\right) / R_{\text {standard }}\right] \times 1000$

where $\mathrm{X}$ is ${ }^{13} \mathrm{C}$ or ${ }^{15} \mathrm{~N}$ and $\mathrm{R}$ is the corresponding ratio $\left({ }^{13} \mathrm{C} /{ }^{12} \mathrm{C}\right.$ or $\left.{ }^{15} \mathrm{~N} /{ }^{14} \mathrm{~N}\right)$. Carbon and nitrogen ratios are expressed relative to the Vienna Pee Dee Belemnite (V-PDB) standard and to atmospheric nitrogen, respectively. Reference materials were IAEA CH-6 (sucrose) $\left(\delta^{13} \mathrm{C}=-10.4 \pm 0.2 \%\right)$ and IAEA-N1 $\left(\delta^{15} \mathrm{~N}=+0.4\right.$ $\pm 0.2 \%$ ), respectively. Internal standards (glycine) were injected at regular intervals during all runs for calibration.

\subsection{Species and life-history stages}

All fish were divided per species into groups according to their general maturity stage and gender to facilitate statistical comparisons. Generally, fish were grouped into mature males (MM), mature females (MF), immature males (IM) and immature females (IF) for each species. For shark species, pre-caudal length, fork length, and total length were measured. For rays, disc width was measured. Maturity of sharks and rays was determined by macroscopic examination of gonads, examination of claspers and siphon sacs on male specimens, or by comparison of shark size with published species-specific size-at-maturity estimates (Brown and Gruber, 1988; Snelson et al., 1988; Natanson et al., 2014; Frazier et al., 2014).

For Atlantic stingrays, the disk width at maturity was $24 \mathrm{~cm}$ for females and $20 \mathrm{~cm}$ for males as reported by Snelson et al. (1988). For bonnetheads, Frazier et al. (2014) reported that the youngest and smallest mature female was $743 \mathrm{~mm}$ fork length, whereas the smallest mature male was $582 \mathrm{~mm}$ fork length. These measurements were used to divide the males and females into groups according to their maturity status. For bull sharks, the Von Bertalanffy growth curves for males and females from Cruz-Martinez et al. (2005) and Natanson et al. (2014) were used to estimate the life history stage of the fish according to their total body length or size (TL). Cruz-Martinez et al. (2005) also reported the age at maturity which was 10 years for females and 9-10 years for males. Natanson et al. (2014) found that males mature at 15-17 years and females at 15 years. However, since all bull sharks in the present study were estimated to be younger than $\sim 3$ years, all animals were immature. For lemon sharks, Von Bertalanffy growth curves (with precaudal lengths instead of total lengths) and ages at maturity as reported by Brown and Gruber (1988) were used. All lemon sharks analyzed in the current study were younger than these reported ages at maturity so all lemon sharks were immature.

\subsection{Statistical analysis}

Statistical analyzes were conducted using the SPSS 20 statistical package (IBM SPSS Statistics 20). The level of statistical significance was defined at $p<0.05$. Non-detects were replaced by a value of $f^{*} \mathrm{LOQ}$ only if $\mathrm{f}$ (frequency of detection) was $>50 \%$. Compounds that were detected in $<50 \%$ of the samples (per species) or not detected at all are given in Table S2, but were not included in further calculations or statistics. Results were notnormally distributed for some compounds in some species, even after log-transformation (Shapiro Wilk's statistical test). In addition, sample sizes of some groups were small. Therefore, nonparametric statistical tests (Kruskal-Wallis statistical tests) were performed to test differences in levels of POPs and MeO-PBDEs between groups or species (taking into account the specific groups). Spearman's correlation coefficients were calculated using GraphPad Prism 6 (GraphPad Software, Inc.). All concentrations are expressed in lipid weight (lw).

\section{Results and discussion}

Biomagnification of several POPs throughout aquatic food webs has been well documented (e.g. Johnson-Restrepo et al., 2005), however, elasmobranchs have been the focus of only few such ecotoxicological studies. Elasmobranchs occupy multiple trophic levels within aquatic ecosystems and play important roles in ecosystem functioning. The present study furthers our understanding of bioaccumulation and potential biomagnification of POPs and MeO-PBDEs in several representative elasmobranch species across multiple life-history stages.

\subsection{Intraspecies results}

\subsubsection{Dasyatis sabina - Atlantic stingray}

In all samples of Atlantic stingrays investigated in this study, 8 compounds were not detected and 25 compounds were detected in $<50 \%$ of the samples (Table S2). The lipid percentages in Atlantic stingrays ranged from $3.5 \%$ to $51.9 \%$. Due to the low sample sizes for immature animals $(n=2)$, statistical tests were only performed between the mature males (MM) and females (MF). Among the mature females, there was one outlier with extremely high concentrations (Table 2), which is likely indicative of the known contaminated condition of the coastal river system where it was collected (Eau Gallie River) (Trocine and Trefry, 1993; Trefry et al., 2008; Trefry and Trocine, 2011). This outlier was excluded from statistical calculations.

3.1.1.1. Profiles. Levels of $\Sigma$ PCBs $>\Sigma$ CHLs $>p$, $p^{\prime}$-DDE, BDE 47 with $p, p^{\prime}$-DDE and BDE 47 being the only compounds among the DDXs and PBDEs, respectively, detected in $>50 \%$ of all samples (Table 2 ). MeO-PBDEs and HCB were detected in $<50 \%$ of all samples or were not detected at all (Table S2). PCB 153 was the most dominant congener in all samples (about $25 \%$ of $\Sigma$ PCBs), followed by either PCB 138, PCB 187, РCB 180 or PCB 196/203 independent of life history stage or gender. Based on the number of $\mathrm{Cl}$-atoms, only the higher chlorinated PCBs, starting from the penta-PCBs (PCB 99) could be detected in $>50 \%$ of the samples. TN was the most 
Table 2

Levels of $\Sigma$ PCBs, $\Sigma$ CHLs, $p, p^{\prime}$-DDE and BDE 47 in liver of Atlantic stingray (Dasyatis sabina) from Florida. Values are medians and (min-max), expressed in $\mathrm{ng} / \mathrm{g}$ lw. ${ }^{*}$ - value $<$ LOQ for that specific compound. $\mathrm{IF}=$ immature female, $\mathrm{MF}=$ mature female, $\mathrm{IM}=$ immature male, $\mathrm{MM}=$ mature male.

\begin{tabular}{llllll}
\hline & IF & MF & IM & MM & $\begin{array}{l}\text { MF } \\
\text { outlier }\end{array}$ \\
\hline$N$ & 1 & 8 & & & 1 \\
Disk $(\mathrm{mm})$ & 196 & $276(233-314)$ & 199 & $263(223-265)$ & 261 \\
$\Sigma$ PCB & 224 & $621(265-2150)$ & 701 & $869(711-1850)$ & 14700 \\
$\Sigma$ CHL & 63 & $42(11-252)$ & 226 & $21(18-69)$ & 2990 \\
$p, p^{\prime}-$ DDE & 11 & $3\left(2^{*}-19\right)$ & 37 & $2^{*}\left(2^{*}-11\right)$ & 447 \\
BDE 47 & 1 & $2\left(1^{*}-46\right)$ & 8 & $5\left(1^{*}-26\right)$ & 44 \\
\hline
\end{tabular}

dominant compound in the majority of the samples (about $40 \%$ of $\Sigma$ CHLS).

3.1.1.2. Levels. There were no statistically significant differences in PCB 153, PCB 138, PCB 187, PCB 180, PCB 196/203, $\Sigma$ PCB, TN, CC, $\Sigma$ CHL, $p, p^{\prime}$-DDE or BDE 47 levels between MF and MM ( $p$-values for all comparisons ranged from 0.221 to 0.838 ; Table 2). Positive correlations were found between $\Sigma$ PCBs and disk width as a measure of growth of the animals. This correlation was statistically significant for females ( $p=0.031$ ), but not for males ( $p=0.083$; Fig. S1(A)). In contrast, negative correlations were found between $\Sigma$ CHLs, $p, p^{\prime}$-DDE and BDE 47 and disk width, respectively, though these were only statistically significant for $\mathrm{p}, \mathrm{p}^{\prime}$-DDE $(p=0.019$ for females and $p<0.001$ for males; Fig. S1(B-D)). The concentrations of total PCBs in liver samples of Atlantic stingrays ranged from 121 to $2150 \mathrm{ng} / \mathrm{g}$ lw with an outlier of $14,700 \mathrm{ng} / \mathrm{g} \mathrm{lw}$ (adult female). Johnson-Restrepo et al. (2005) analyzed muscle samples of Atlantic stingrays from the same region and found PCB levels ranging from 68 to $3160 \mathrm{ng} / \mathrm{g}$ lw (mean $592 \mathrm{ng} / \mathrm{g} \mathrm{lw}$ ) which is slightly higher than the results from the present study. Assuming a lipid percentage of $20 \%$ in the liver, which is the overall mean lipid percentage of the stingrays in the present study, Gelsleichter et al. (2006) found a mean PCB concentration of $485 \mathrm{ng} / \mathrm{g}$ lw in liver samples of Atlantic stingrays from Tampa Bay, Florida. Total PCB levels ranged from 260 to $605 \mathrm{ng} / \mathrm{g}$ lw in liver of Atlantic stingrays from several freshwater areas of the Saint Johns River in central Florida (Gelsleichter et al., 2006). Compared to Gelsleichter et al. (2006), DDX and CHL levels in the present study were lower. Johnson-Restrepo et al. (2005) reported higher levels of BDE 47 in muscle of Atlantic stingrays (range: $2-83 \mathrm{ng} / \mathrm{g}$ lw; mean: $42 \mathrm{ng} / \mathrm{g}$ lw) than in liver examined in this species in the present study.

\subsubsection{Sphyrna tiburo - bonnethead}

In all samples of bonnetheads investigated in this study, 12 compounds were not detected and 16 compounds were detected in $<50 \%$ of the samples (Table S2). Livers of one neonate, one MM, one IF and $16 \mathrm{MF}$ were investigated. The lipid percentages ranged from $7.3 \%$ to $55.1 \%$. Due to the low sample sizes for three life history stage/gender groups ( $n=1$ for neonates, MM and IF), comparisons between groups could not be statistically tested. Furthermore, due to the small sample sizes of the male groups, correlations between the levels of the POP classes and the body sizes of the males were not assessed.

3.1.2.1. Profiles. Levels of $\Sigma$ PCBs $>p, p^{\prime}$-DDE $>\sum$ CHLs $>\sum$ PBDEs and 6-MeO-BDE 47 with the exception of one mature female in which the levels of $\sum$ CHLs were higher than those of $p, p^{\prime}$-DDE (Table 3). p,p'-DDE and 6-MeO-BDE 47 were the only compounds among the DDXs and MeO-PBDEs, respectively, detected in $>50 \%$ of all samples. HCB was detected in $<50 \%$ of all samples (Table S2). PCB 153 was not the only dominant congener, but switched

\section{Table 3}

Levels of $\Sigma$ PCBs, $\Sigma$ CHLs, $p, p^{\prime}$-DDE, $\Sigma$ PBDEs and 6-MeO-BDE 47 in liver of bonnetheads (Sphyrna tiburo) from Florida. Values are medians and ( $\mathrm{min}-\mathrm{max}$ ), expressed in $\mathrm{ng} / \mathrm{g}$ lw. ${ }^{*}$ - value $<$ LOQ for that specific compound. TL - total length. $\mathrm{IF}=$ immature female, $\mathrm{MM}=$ mature male, $\mathrm{MF}=$ mature female.

\begin{tabular}{lllll}
\hline & Neonate & IF & MM & MF \\
\hline$N$ & 1 & 1 & 1 & 16 \\
TL $(\mathrm{mm})$ & 406 & 654 & 910 & $1070(756-1200)$ \\
$\Sigma$ PCB & 8900 & 10,600 & 68,900 & $3150(880-12100)$ \\
$p, p^{\prime}-\mathrm{DDE}$ & 56 & 76 & 1500 & $121(55-602)$ \\
$\sum$ CHL & 26 & 55 & 295 & $53(21-218)$ \\
$\sum$ PBDE & 6 & 4 & 100 & $14(4-55)$ \\
6-MeO-BDE 47 & $1^{*}$ & 8 & $1^{*}$ & $4\left(1^{*}-15\right)$ \\
\hline
\end{tabular}

places with PCB 206, PCB 180 or PCB 199 which could not be explained by factors such as life history stage or gender. TN was the most dominant compound in all samples representing about 51\% of the sum of CHLs and was followed by either CN or OxC. From the two PBDE congeners detected in $>50 \%$ of the samples, BDE 47 was predominant followed by BDE 100 .

3.1.2.2. Levels. Levels of $\Sigma$ PCBs in the liver of the neonate, mature male and immature female were $8900,68,900$ and $10,600 \mathrm{ng} / \mathrm{g}$ lw, respectively (Table 3). The median level of $\Sigma$ PCBs in MF was lower than the levels measured in the neonate, IF and MM whereas levels in MM were the highest. Concentrations of $p, p$ '-DDE in the livers of the sharks ranged from 56 to $1520 \mathrm{ng} / \mathrm{g}$ lw which were the concentrations measured in the neonate and in the mature male, respectively. The same, namely the lowest levels in the neonate and the highest levels in the mature male, was also found for $\Sigma$ CHLs (26-295 ng/g lw). This suggests that concentrations were increasing with bonnethead size and life history stage. The mature male also had the highest concentration (100 ng/g lw) of $\Sigma$ PBDEs, while the immature female, not the neonate, had the lowest concentration ( $4 \mathrm{ng} / \mathrm{g} \mathrm{lw}$ ). However, in contrast to all these findings so far, concentrations of 6-MeO-BDE 47 were highest in the immature female while levels were $<$ LOQ in the mature male and neonate. Levels of $\Sigma$ PCBs, $p, p^{\prime}$-DDE, $\Sigma$ CHLs and $\Sigma$ PBDEs were positively correlated with body length of bonnetheads, though this was not always statistically significant (Fig. S2(A-D)). On the other hand, levels of 6-MeO-BDE 47 were negatively correlated with the body length of females (Spearman's $r=-0.027 ; p=0.915$; Fig. S2(E)).

\subsubsection{Carcharhinus leucas - bull shark}

In all samples of bull sharks investigated in this study (liver of 5 neonates, 3 immature males), 6 compounds were not detected at all in any sample and 6 compounds were detected in $<50 \%$ of the samples (Table S2). The lipid percentages varied from $55.9 \%$ to $74.7 \%$. Due to the low sample sizes for immature males and male neonates, comparisons could not be statistically tested. Spearman's correlation tests were not performed due to the small sample sizes for females $(n=4)$ and males $(n=3)$. Nevertheless, graphs representing the concentrations versus the growth of the animals can be found in the Supporting Information (Fig. S3(A)-(F)).

$\begin{array}{llll}\text { 3.1.3.1. Profiles. Levels of } \Sigma & \text { PCBs }>\Sigma & \text { DDXs }>\Sigma & \text { CHLs }>\Sigma\end{array}$ PBDEs $>\Sigma$ MeO-PBDEs $>$ HCB, except for one immature male which had $\Sigma$ CHLs $>\Sigma$ DDXs (Table 4). PCB 153 was the most dominant $\mathrm{PCB}$ congener in all samples (about $27 \%$ of $\Sigma$ PCBs), followed by PCB 138. The next congener after PCB 138 was either PCB 99 or PCB 187. The only exception to this pattern was the same immature male that had a different order of $\Sigma$ CHLs and $\Sigma$ DDXs compared to all other bull sharks. This particular male had higher 
Table 4

Levels of $\Sigma$ PCBs, $\Sigma$ DDXs, $\Sigma$ CHLs, $\Sigma$ PBDEs, $\Sigma$ MeO-PBDEs and HCB in liver of bull sharks (Carcharhinus leucas) from Florida. Values are medians and (min-max), expressed in ng/g lw. ${ }^{*}$ - value $<$ LOQ for that specific compound. TL - total length. $\mathrm{IM}=$ immature male.

\begin{tabular}{llll}
\hline & Female neonate & Male neonate & IM \\
\hline$N$ & 4 & 1 & 3 \\
TL $(\mathrm{mm})$ & $729(674-825)$ & 809 & $902(844-1120)$ \\
$\Sigma$ PCB & $12,500(4700-18,900)$ & 32,000 & $7200(1780-10,300)$ \\
$\Sigma$ DDX & $5290(1850-12,400)$ & 19900 & $2120(416-4320)$ \\
$\Sigma$ CHL & $1560(535-2350)$ & 3440 & $613(518-871)$ \\
$\Sigma$ PBDE & $429(146-524)$ & 835 & $203(60-209)$ \\
$\Sigma$ MeO-PBDE & $57(27-64)$ & 56 & $45(41-65)$ \\
HCB & $2\left(1^{*}-5\right)$ & 5 & $2\left(1^{*}-2\right)$ \\
\hline
\end{tabular}

levels of PCB 187 followed by PCB 138. Concentrations of $p, p^{\prime}$-DDE were highest in all samples followed by $p, p^{\prime}$-DDD and $p, p^{\prime}$-DDT. The $0, p^{\prime}$-isomers were not detected in any sample (DDE and DDD) or were only detected in $<50 \%$ of all samples (DDT) (Table S2). TN was the most dominant compound in all samples (about $76 \%$ of $\Sigma$ CHLs) followed by $\mathrm{CN}$. The only exception to this pattern was the same immature male which also had deviating patterns for some of the PCB congeners and a reversed order of $\Sigma$ CHLs and $\Sigma$ DDXs compared to all other bull sharks. All PBDE congeners were detected in $>50 \%$ of the samples of bull sharks analyzed. BDE 47 is predominant followed by BDE 100 . BDE 99 has the lowest levels in all samples. Both 2-MeO-BDE 68 and 6-MeO-BDE 47 were detected in all samples. 2-MeO-BDE 68 had the highest levels in 6 out of 8 samples in which its percentage was on average $63 \%$. HCB was detected in 5 out of 8 samples and mostly in levels close to the $\mathrm{LOQ}(\mathrm{LOQ}=2 \mathrm{ng} / \mathrm{g} \mathrm{lw})$.

3.1.3.2. Levels. Levels of $\Sigma$ PCBs, $\Sigma$ DDXs and $\sum$ PBDEs in the livers of the neonates (both female and male) were higher than the levels in the livers of the immature males, whereas the levels of $\Sigma$ $\mathrm{MeO}-\mathrm{PBDEs}$ were fairly similar in all life history stage-gender groups without any apparent trend (Table 4). Total PCB levels in bull sharks ranged from 1780 to $32,000 \mathrm{ng} / \mathrm{g} \mathrm{lw}$. This range exceeds the results found in muscle samples of the same species from 1993 to 1994 (range: 3930-8310 ng/g lw; Johnson-Restrepo et al., 2005) and from 2006 to 2008 (range: 310-22100 ng/g lw; Olin et al., 2014), but not results from 2002 to 2004 (range: 2930327000 ng/g lw; Johnson-Restrepo et al., 2005).

\subsubsection{Negaprion brevirostris - lemon shark}

In all samples of lemon sharks investigated in this study (liver of 1 female neonate, 8 immature females and 3 immature males), 14 compounds were not detected at all, and 4 compounds were detected in $<50 \%$ of the samples (Table S2). The lipid percentages varied from $38.1 \%$ to $70.7 \%$. Due to the low sample size for the neonate $(n=1)$, this animal was not included in the statistical analysis. Statistics were therefore only performed for IF and IM.

3.1.4.1. Profiles. In contrast to the bull sharks, $\mathrm{HCB}$ was not detected in any of the lemon sharks. Levels of $\Sigma$ PCBs were highest, followed by $\Sigma$ DDXs and $\Sigma$ CHLs, respectively. $\Sigma$ PBDEs and $\Sigma$ MeO-PBDEs had the lowest levels (Table 5). Similar to results for bonnetheads, PCB 153 was not the most dominant congener in all samples among PCBs. PCB 153 was predominant in 7 out of 12 samples, but PCB 206 was predominant in the remaining 5 samples. These two congeners were followed by PCBs 99, 138, 180, 199 and 196/203 without a clear pattern of distribution. Concentrations of $p, p^{\prime}$-DDE were highest representing about $91 \%$ of the total concentration of DDXs. TN was the most dominant compound in all samples among CHLs (44\% of $\Sigma$ CHLs). Concentrations of BDE 47 were consistently highest of all PBDEs in all lemon sharks,
Table 5

Levels of $\Sigma$ PCBs, $\Sigma$ DDXs, $\Sigma$ CHLs, $\Sigma$ PBDEs and $\Sigma$ MeO-PBDEs in liver of lemon sharks (Negaprion brevirostris) from Florida. Values are medians and (min-max), expressed in ng/g lw. ${ }^{*}-$ value $<$ LOQ for that specific compound. PCL - precaudal length. $\mathrm{IF}=$ immature female, $\mathrm{IM}=$ immature male.

\begin{tabular}{llll}
\hline & Female neonate & IF & IM \\
\hline$N$ & 1 & 8 & 3 \\
PCL $(\mathrm{mm})$ & 490 & $616(550-821)$ & $844(624-944)$ \\
$\Sigma$ PCB & 1400 & $2690(729-5610)$ & $1770(627-4040)$ \\
$\Sigma$ DDX & 243 & $251(118-756)$ & $322(252-675)$ \\
$\Sigma$ CHL & 116 & $109(40-260)$ & $73(55-221)$ \\
$\Sigma$ PBDE & 49 & $31(12-103)$ & $18(17-96)$ \\
$\Sigma$ MeO-PBDEs & 2 & $12(2-24)$ & $16(12-22)$ \\
\hline
\end{tabular}

followed by BDE 100 . In contrast to the bull sharks, concentrations of 6-MeO-BDE 47 were predominant instead of 2-MeO-BDE 68 for the MeO-PBDEs.

3.1.4.2. Levels. Levels of $\Sigma$ PCBs in the livers of the female neonate was $1410 \mathrm{ng} / \mathrm{g} \mathrm{lw}$ and median levels in the immature females and males were 2690 and $1770 \mathrm{ng} / \mathrm{g} \mathrm{lw}$, respectively. There were no statistically significant differences in PCB 153, РСВ 206, РСВ 99, PCB 138, PCB 180, PCB 199, РCB 196/203, $\Sigma$ PCBs, p, $p^{\prime}$-DDE, $\Sigma$ DDXs, TN, $\Sigma$ CHLs, BDE 47, BDE 100 or $\Sigma$ PBDE levels between IF and IM ( $p$-values ranged from 0.414 to 0.838 ). Correlations between the levels of the compounds and the precaudal length were made (Fig. S4(A-E), but straightforward conclusions could not be drawn and none of these correlations were statistically significant.

\subsection{Interspecies comparisons}

\subsubsection{Profiles}

More compounds were not detected or were detected in $<50 \%$ of Atlantic stingrays (33 compounds) and bonnethead (28 compounds) than compounds not detected in lemon (18 compounds) and bull sharks (12 compounds) (Table S2). Generally, more compounds were detected in higher trophic-level species compared to lower trophic-level species examined. These differences can likely be explained by a combination of differences in trophic transfer of certain chemicals, species-specific feeding ecologies, variation in POP concentrations in different prey types, and metabolic capacity of the shark and ray species examined. In terms of the number of compounds measured in $>50 \%$ of the samples, the bull sharks had the highest number and Atlantic stingrays the lowest number. Several of the higher chlorinated PCBs, higher brominated PBDEs and $p, p^{\prime}$-DDXs (DDD and DDT) were more frequently measured in the shark species than in the stingrays. The only exception to this is PCB 174 which was detected in more than $50 \%$ of the stingray samples whereas it was only detected in some shark samples. 6-MeO-BDE 47 was not detected in any stingray samples and had the highest levels among all MeO-PBDEs in bonnetheads and lemon sharks. Two bull sharks, however, had higher levels of 2-MeO-BDE 68 than 6-MeO-BDE 47.

\subsubsection{Levels}

Due to the high diversity of compound types and the large number of compounds measured in all samples, it is not feasible to include and interpret all measured compounds with regard to interspecies comparisons. Therefore, a selection was made based on the predominance of the compounds within each compound class and species. For all species combined, the sum of PCBs consisted of 8 different congeners ( ${ }^{8} \Sigma$ PCB), namely PCB 99, 138, 153 , $180,187,199,196 / 203$ and 206 . The sum of CHLs ( ${ }^{3} \Sigma$ CHL) consisted of TN, CC and CN. For DDXs and PBDEs, the only compounds included in the interspecies comparisons were $p, p^{\prime}-\mathrm{DDE}$ and $\mathrm{BDE}$ 
${ }^{8} \sum$ PCB

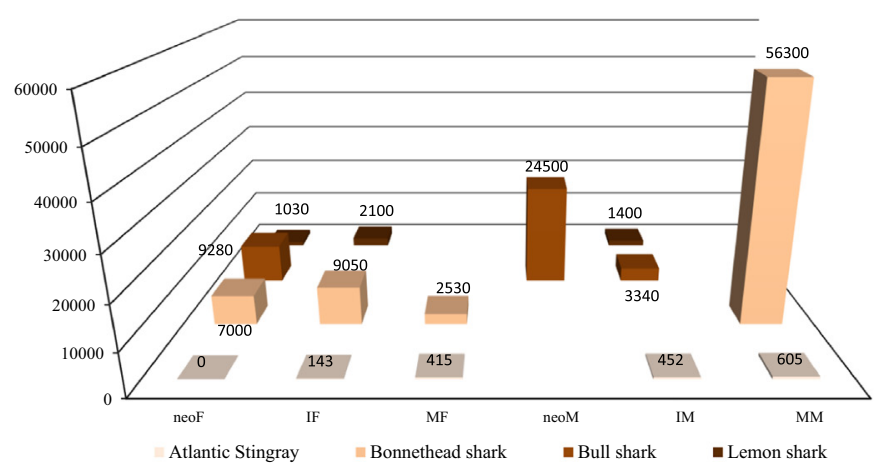

${ }^{3} \sum$ CHLs

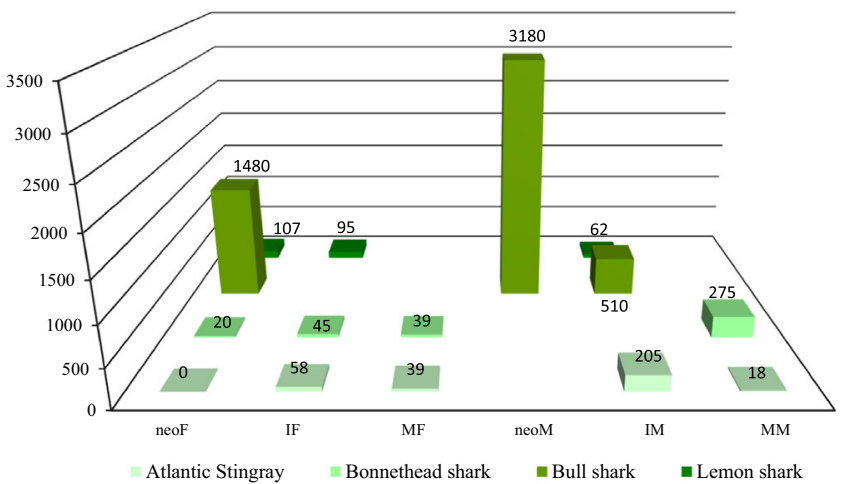

HCB

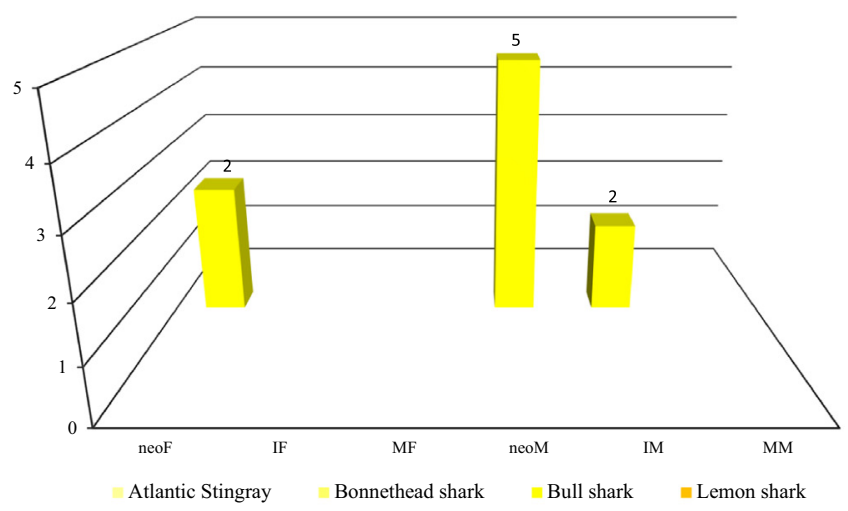

$p, p$ '-DDE

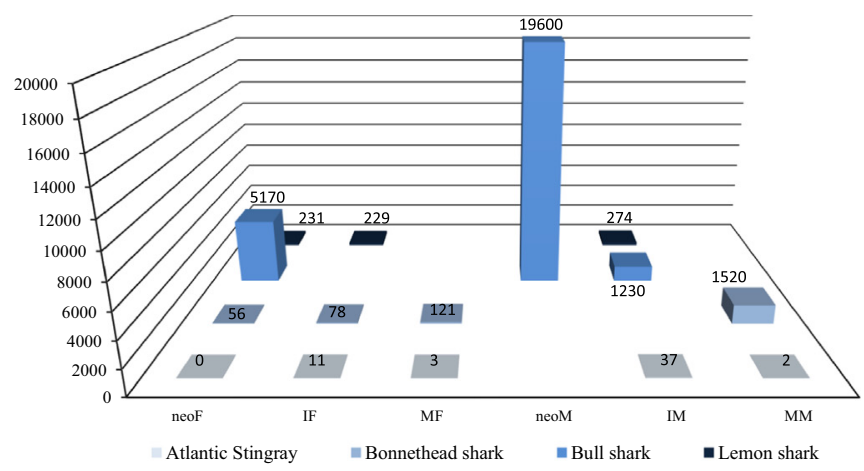

BDE 47

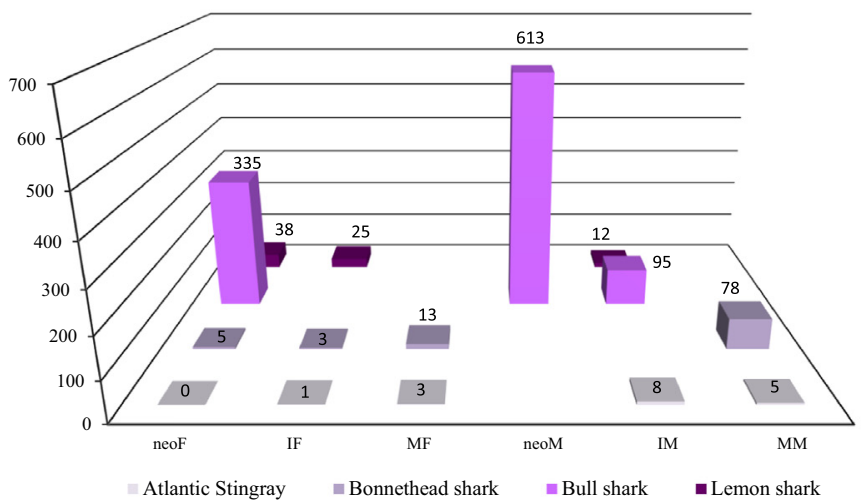

6-MeO-BDE 47

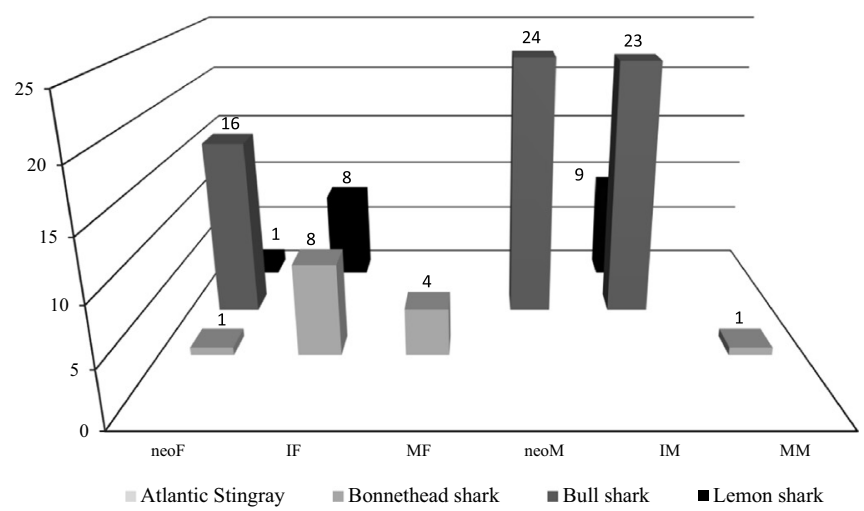

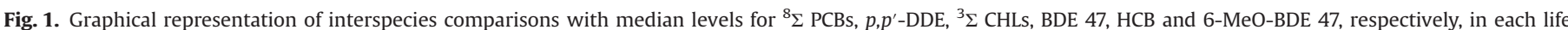

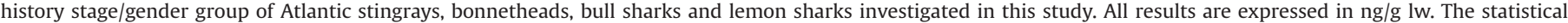
outlier (mature female) for the Atlantic stingrays is not shown.

47, respectively. 6-MeO-BDE 47 and HCB were also included even though both compounds were not detected at all in the Atlantic stingrays. The graphical representation of the interspecies differences shows four major trends (Fig. 1): (1) the highest levels for ${ }^{3} \Sigma$ CHLs, $p, p^{\prime}$-DDE, BDE 47, 6-MeO-BDE 47 and HCB were found for male neonate bull sharks followed by female neonate bull sharks and immature male bull sharks. This was not true for the ${ }^{8} \Sigma$ PCBs, for which mature male bonnetheads had the highest levels. Considering the trophic position of these species, based on stomach content analyzes in other studies (e.g. Cortés, 1999), these findings do not show a straightforward pattern of bioaccumulation or biomagnification of POPs. (2) HCB was only detected at measurable levels in bull sharks and was detected in all bull sharks examined in this study. (3) 6-MeO-BDE 47 was not detected in any stingray sample, but was present in the samples of all three shark species. (4) Compared to the other life history stage/gender groups of the other species, PCBs have a prominent role in the total body burden of compounds analyzed in the present study in bonnetheads. Additionally, comparisons reveal that bull shark neonates and juveniles often have considerable, if not the highest, levels of most POPs when compared to other species examined. These high POP concentrations of neonate bull sharks likely reflect maternal signatures transferred in utero, but POP concentrations of juveniles (approximately 1-3 years of age) also more accurately reflect 
concentrations in IRL prey they consume. This is further supported by results of Olin et al. (2014) from immature bull sharks caught in two rivers of the Gulf coast of Florida in 2006-2008.

Toxicological data for PCBs, DDXs, CHLs, HCB, PBDEs and MeOPBDEs in elasmobranchs are scarce compared to other fish species. Additionally, studies do not always include the same number and type of compounds, which makes comparisons difficult. The presence of higher chlorinated PCBs in elasmobranchs rather than the lower chlorinated congeners seems typical across these species. This has been reported earlier for other species, such as gulper sharks, Centrophorus granulosus, and longnose spurdogs Squalus blainvillei (Storelli and Marcotrigiano, 2001), eight shark species from northwest Africa (Serrano et al., 2000), blue sharks, Prionace glauca, and kitefin sharks Dalatias licha (Storelli et al., 2005) and Atlantic stingrays from Florida (Johnson-Restrepo et al., 2005). Overall, penta-, hexa- and hepta-PCBs were the most dominant in all species of the present study. However, the contribution of hepta- to nona-PCBs was higher for bonnetheads, which infers another source of contamination might be involved. Similarly, in bottlenose dolphins from Georgia, USA, higher chlorinated PCBs starting from the octa-PCBs were also found to dominate in the overall PCB pattern (Balmer et al., 2011; Kucklick et al., 2011). These congeners were associated with the commercial PCB mixture Aroclor 1268 which was linked earlier to the Linden Chemicals and Plastic (LCP) Superfund site in the Brunswick estuary in Georgia (Kannan et al., 1997; Pulster and Maruya, 2008).

Among DDXs, $p, p^{\prime}$-DDE was the most dominant DDX in all species in the present study which was also true in liver samples of other elasmobranch species (Storelli and Marcotrigiano, 2001; Schlenk et al., 2005; Storelli et al., 2005; Gelsleichter et al., 2006; Cornish et al., 2007). The ratio of DDE/ $\Sigma$ DDX is used to determine the degree or duration of DDT contamination. Aguilar (1984) suggested that a ratio smaller than 0.6 points towards a new or recent input of DDT in to the system, whereas a ratio greater than 0.6 indicates a relatively stable system. Ratios in the present research varied from 0.76 to 0.99 which suggests that there has been no recent DDT input in the estuarine and marine ecosystem in waters of our study region in Florida.

For the CHLs, TN and CN were identified as the most dominant compounds in all species in this study, which was similar to the results for bonnetheads in estuaries on the Gulf of Mexico coast of Florida (Gelsleichter et al., 2005). For the PBDEs, there was a predominance of BDE 47 in all species investigated and this congener was followed by BDE 100 and BDE 154, 28 or 153, except for Atlantic stingrays. Concentrations of BDE 99 were negligible which may indicate a relatively quick and easy metabolic breakdown of this congener in elasmobranchs in favor of BDE 47, as shown for common carp (Cyprinus carpio; Stapleton et al., 2004). The PBDE pattern in shark species in the present study was also found in other marine species from Florida, such as sea turtles (Keller et al., 2005 and 2007).

Juvenile lemon sharks we examined were from an adjacent nearshore (non-estuarine) nursery ground (in the Atlantic Ocean directly off Cape Canaveral, directly adjacent to the IRL) occur at generally the same latitude as the juvenile bull sharks we examined that were all from estuarine IRL waters. These were adjacent, but drastically different core nursery habitats (Adams and Paperno, 2007). Concentrations of all compounds investigated in the present study were lower in the juvenile lemon sharks than the juvenile bull sharks. Bonnetheads in this study had concentrations ranging from 880 to $68,900 \mathrm{ng} / \mathrm{g}$ lw of total PCBs, exceeded thus the values found in bonnetheads from other areas of the southeastern USA in Gelsleichter et al. (2008) (mean 241 to $3540 \mathrm{ng} / \mathrm{g} \mathrm{lw}$ ). The DDX and CHL levels in the bonnetheads of the present study were similar to the results from Gelsleichter et al. (2005 and 2008) except for bonnetheads from Anclote Key,
Florida, which had significantly higher CHL values. All bonnetheads investigated in this study were from estuarine or nearshore waters of the Atlantic coast in Florida, although they do not reside at the same place all the time. Past tagging data suggests that this species is philopatric, but at the same time, they were found to be able to move relatively long distances within the Atlantic US coast. Overall, this population has been found to remain in the general South Carolina - Florida region without moving into the Gulf of Mexico (Driggers et al., 2013, 2014). Expansive use of multiple habitat types and regions likely influences the variability in the results we found in this species. Though there are studies who have investigated MeO-PBDEs in tiger sharks (Galeocerdo cuvier; Haraguchi et al., 2009), Greenland sharks (Somniosus microcephalus; Strid et al., 2010) and scalloped hammerhead sharks (Sphyrna lewini; Nomiyama et al., 2011), this is the first study, to our knowledge, to examine PBDEs and MeO-PBDEs in bonnetheads and lemon sharks.

\subsection{Stable isotopes and POPS}

The values of $\delta^{13} \mathrm{C}$ and $\delta^{15} \mathrm{~N}$ as measured in muscle samples of some Atlantic stingrays $(n=14$; Table 1$)$ and a bonnethead $(n=1$; Table 1 ) are given in Fig. S5. Visually, $\delta^{13} \mathrm{C}$ values were higher in most Atlantic stingrays than in bonnetheads. With the exception of one Atlantic stingray, $\delta^{15} \mathrm{~N}$-values seem to be higher in stingrays compared to bonnetheads. Taking into account the concentrations of several POPs and MeO-PBDEs as measured in the liver of the same animals (Fig. S5), the bonnethead had higher levels of ${ }^{8} \Sigma$ PCBs and $p, p^{\prime}$-DDE compared to all Atlantic stingray with the exception of one stingray outlier. The bonnethead had comparable levels of ${ }^{3} \Sigma$ CHLs and intermediate levels of BDE 47 compared to the levels in the stingrays. There was an outlier for all compound classes among the Atlantic stingrays which had the lowest $\delta^{13} \mathrm{C}$ values but the highest $\delta^{15} \mathrm{~N}$ values and POP levels of all stingrays included in this part of the study. Atlantic stingrays and bonnetheads are two common species in waters of the southeastern USA. Atlantic stingrays and juvenile bull sharks occur in the same estuarine habitat types within the IRL and juvenile bull sharks regularly prey on Atlantic stingrays in the IRL system. The stingrays are opportunistic predators, whereas the bonnetheads typically show a more specialist feeding behavior directed towards crustaceans (e.g. Callinectes sapidus, blue crabs). Although the prey species composition is drastically different for each of these species, both feed principally on invertebrates (Kajiura and Tricas, 1996; Lessa and Almeida, 1998), with a small proportion of fish in their overall diets (Cook, 1994; Lessa and Almeida, 1998; Olin et al., 2013) placing them on a relatively low trophic level in the system (Cortés, 1999; Olin et al., 2013). Out of 149 shark species, bonnetheads had the second lowest trophic level together with three other shark species (trophic level of 3.2; calculations by Cortés (1999)). The same calculations rendered trophic level values of 4.2 for lemon and 4.3 for bull sharks (Cortés, 1999). Since muscle samples of lemon sharks examined in this study were not available to measure stable isotopes, the trophic position of this species could not be directly assessed here. Two juvenile bull sharks from the IRL were recently analyzed for stable isotopes and had $\delta^{15} \mathrm{~N}$ values of 13.22 and $13.55 \%$ and $\delta^{13} \mathrm{C}$ values of -15.88 and $-16.20 \%$ (Nifong and Adams (personal communication)). For bonnetheads, a mean $\delta^{15} \mathrm{~N}$ value from Olin et al. (2013) was $\sim 12.1 \%$ (mean calculated from individual data points obtained by digitizing Fig. 4(a) from Olin et al. (2013)). This value was higher than the $\delta^{15} \mathrm{~N}$ measured in the bonnethead female in the present study which was $9.76 \%$ and was comparable to the $\delta^{15} \mathrm{~N}$ values found in muscle for juvenile bull sharks (range $=11.07-13.26 \%$ in Matich et al. (2010); $13.22 \%$ and 13.55\% from Nifong and Adams (personal communication)). Olin et al. (2013) investigated shark 
species from two different sites, Georgia (USA) and South-Africa. Ecosystem dynamics and available prey bases in these two system likely differ from our study area in Florida, which may explain these stable isotope differences. Matich et al. (2010) investigated juvenile bull sharks from the Shark River Estuary of the Everglades National Park in Florida and Nifong and Adams (personal communication) investigated 2 juvenile bull sharks from the IRL system. From these results, both bonnetheads and Atlantic stingrays are in lower trophic positions compared to juvenile bull sharks.

\subsection{Toxic effects?}

Relationships between levels of POPs and reproductive success or immune system function in Atlantic stingrays were investigated by Gelsleichter et al. (2006). That study reported hepatic PCB levels of $52-121 \mathrm{ng} / \mathrm{g}$ ww (or 260-605 ng/g lw with an assumed average lipid percentage of 20\%) and DDX levels of 20-80 ng/g ww in Atlantic stingrays. These levels did not appear to influence reproduction. However, elevated serum steroid concentrations and white blood cell counts were observed in the most contaminated individuals, suggesting that immune system issues may arise with higher POP levels. Concentrations of both PCBs and DDXs in Atlantic stingrays of the present study were similar or much higher than concentrations in Atlantic stingrays examined by Gelsleichter et al. (2006), suggesting that these stingrays may be experiencing toxic effects of PCBs and DDXs on their immune systems. Concentrations of DDXs are comparatively higher in the shark species examined in this study, however, the effects of these compounds on these species is currently unknown.

\section{Conclusions}

In general, bull sharks had the highest levels of POPs and MeOPBDEs measured of the four elasmobranch species in the present study, as well as higher $\delta^{15} \mathrm{~N}$ values compared to the bonnetheads. This supports a bioaccumulation and biomagnification theory in this particular food web. Bull sharks were the only species in the present study where $\mathrm{HCB}$ was detected. Contrastingly, Atlantic stingrays from the same IRL estuarine waters were the only species in the present study where MeO-PBDEs were not detected. Although both species co-occur in similar habitats within the IRL system, different feeding ecologies and species-specific metabolism likely influence POP and MeO-PBDE levels and profiles. Atlantic stingrays experience a slightly decreasing trend in $\mathrm{PCB}$ and PBDE levels with life history stage, but this was not apparent for the species that are more towards the top of the trophic system. However, even with this decreasing trend, levels of some Atlantic stingrays were higher than concentrations that were linked to adverse health effects for this species. As information regarding the direct effects of POPs is not available for shark species, potential heath effects of these compounds at concentrations found in our study are currently unknown.

\section{Acknowledgements}

LW was financially supported by the Scientific Research Foundation (FWO). AC is grateful to the University of Antwerp (UA) for financial support. KD and GL are F.R.S.-FNRS Research Associates. Sharks and stingrays for this study were collected by the Florida Fish and Wildlife Conservation Commission - Fish and Wildlife Research Institute's Fisheries-Independent Monitoring Program. We very much appreciate additional lemon shark samples provided by Eric Reyier of NASA's Kennedy Space Center Ecological Program.

\section{Appendix A. Supplementary material}

Supplementary data associated with this article can be found in the online version at http://dx.doi.org/10.1016/j.envres.2014.12. 022 .

\section{References}

Adams, D.H., Paperno, R., 2007. Preliminary assessment of a nearshore nursery ground for the scalloped hammerhead off the Atlantic Coast of Florida. Am. Fish. Soc. Symp. 50, 165-174.

Aguilar, A., 1984. Relationship of DDE/ $\mathrm{DDDT}$ in marine mammals to the chronology of DDT input into the ecosystem. Can. J. Fish. Aquat. Sci. 41, 840-844.

Balmer, B.C., Schwacke, L.H., Wells, R.S., George, R.C., Hoguet, J., Kucklick, J.R., Lane S.M., Martinez, A., McLellan, W.A., Rosel, P.E., Rowles, T.K., Sparks, K., Speakman, T., Zolman, E.S., Pabst, D.A., 2011. Relationship between persistent organic pollutants (POPs) and ranging patterns in common bottlenose dolphins (Tursiops truncatus) from coastal Georgia, USA. Sci. Total Environ. 409, 2094-2101.

Bethea, D.M., Hollensead, L., Carlson, J.K., 2006. Shark nursery grounds and essential fish habitat studies. Report to NOAA Fisheries, Panama City, FL., pp. 64

Bethea, D.M., Hale, L., Carlson, J.K., Cortés, E., Manire, C.A., Gelsleichter, J., 2007. Geographic and ontogenetic variation in the diet and daily ration of the bonnethead shark, Sphyrna tiburo, from the eastern Gulf of Mexico. Mar. Biol. 152, 1009-1020.

Bone, Q., Moore, R., 2008. Biology of Fishes. In: Owen, E. (Ed.), third ed. Taylor \& Francis group, Abingdon, UK.

Brown, C.A., Gruber, S.H., 1988. Age assessments of the lemon shark, Negaprion brevirostris, using tetracycline validated vertebral centra. Copeia 3, 747-753.

Carlson, J.K., Ribera, M.M., Conrath, C.L., Heupel, M.R., Burgess, G.H., 2010. Habitat use and movement patterns of bull sharks Carcharhinus leucas determined using pop-up satellite archival tags. J. Fish Biol. 77, 661-675.

Cook, D.A., 1994. Temporal patterns of food habits of the Atlantic stingray, Dasyatis sabina (Lesueur, 1824) from the Banana River Lagoon Florida. Florida Institute of Technology, p. 45 (MSc thesis).

Cornish, A.S., Ng, W.C., Ho, V.C.M., Wong, H.L., Lam, J.C.W., Lam, P.K.S., Leung, K.M.Y. 2007. Trace metals and organochlorines in the bamboo shark Chiloscyllium plagiosum from the southern waters of Hong Kong, China. Sci. Total Environ. 376, 335-345.

Cortés, E., 1999. Standardized diet compositions and trophic levels of sharks. ICES J. Mar. Sci. 56, 707-717.

Cortés, E., Gruber, S.H., 1990. Diet, feeding habits and estimates of daily ration of young lemon sharks, Negaprion brevirostris ( Poey). Copeia 1, 204-218.

Cortés, E., Manire, C.A., Hueter, R.E., 1996. Diet, feeding habits, and diel feeding chronology of the bonnethead shark, Sphyrna tiburo, in southwest Florida. Bull. Mar. Sci. 58, 353-367.

Cruz-Martinez, A., Chiappa-Carrara, X., Arenas-Fuentes, V., 2005. Age and growth of the bull shark, Carcharhinus leucas, from Southern Gulf of Mexico. J. Northwest Atl. Fish Sci. 35, 367-374.

Curtis, T.H., Adams, D.H., Burgess, G.H., 2011. Seasonal distribution and habitat associations of bull sharks in the Indian River Lagoon, Florida: A 30-year synthesis. Trans. Am. Fish. Soc. 140, 1213-1226.

De Azevedo e Silva, C.E., Azeredo, A., de Cassia Lima Dias, A., Costa, P., Lailson-Brito, J., Malm, O., Daveé Guimaraes, J.R., Machado Torres, J.P.,, 2009. Organochlorine compounds in sharks from the Brazilian coast. Mar. Pollut. Bull. 58, 294-298.

De Boeck, G., Grosell, M., Wood, C., 2001. Sensitivity of the spiny dogfish (Squalus acanthias) to waterborne silver exposure. Aquat. Toxicol. 54, 261-275.

Driggers, W.B. III, Frazier, B.S., Adams, D.H., Ulrich, G.F., Hoffmayer, E.R., 2013. Interannual site fidelity of bonnetheads (Sphyrna tiburo) to two coastal ecosystems in the western North Atlantic Ocean. SEDAR34-WP-23. SEDAR, North Charleston, SC. 31p.

Driggers III, W.B., Frazier, B.S., Adams, D.H., Ulrich, G.F., Jones, C.M., Hoffmayer, E.R. Campbell, M.D., 2014. Site fidelity of migratory bonnethead sharks Sphyrna tiburo (L. 1758) to specific estuaries in South Carolina, USA. J. Exp. Mar. Biol. 459, 61-69.

Eyckmans, M., Lardon, I., Wood, C., De Boeck, G., 2013. Physiological effects of waterborne lead exposure in spiny dogfish (Squalus acanthias). Aquat. Toxicol. 126, 373-381.

Feldheim, K.A., Gruber, S.H., Ashley, M.V., 2002. The breeding biology of lemon sharks at a tropical nursery lagoon. Proc. R. Soc. Lond. B Biol. 269, 1655-1661.

Frazier, B.S., Driggers, W.B., Adams, D.H., Jones, C.M., Loefer, J.K., 2014. Validated age, growth and maturity of the bonnethead Sphyrna tiburo in the western North Atlantic Ocean. J. Fish Biol. 85, 688-712.

Funicelli, N.A., 1975. Taxonomy, Feeding, Limiting Factors and Sex Ratios of Dasyatis americana. The Aquila Digital Community, University of Southern Mississippi, p. 2787 (Dasyatis sayi and Narcine brasiliensis (Doctoral dissertation).

FWC (Florida Fish and Wildlife Conservation Commission), 2014. Florida saltwater recreational fishing regulations. FWC, Tallahassee.

Gelsleichter, J., Manire, C.A., Szabo, N.J., Cortés, E., Carlson, J., Lombardi-Carlson, L. 2005. Organochlorine concentrations in bonnethead sharks (Sphyrna tiburo) from four Florida estuaries. Arch. Environ. Contam. Toxicol. 48, 474-483.

Gelsleichter, J., Walsh, C.J., Szabo, N.J., Rasmussen, L.E.L., 2006. Organochlorine concentrations, reproductive physiology, and immune function in unique 
populations of freshwater Atlantic stingrays (Dasyatis sabina) from Florida's St Johns River. Chemosphere 63, 1506-1522.

Gelsleichter, J., Szabo, N.J., Belcher, C.N., Ulrich, G.F., 2008. Organochlorine contaminants in bonnethead sharks (Sphyrna tiburo) from Atlantic and Gulf estuaries on the US east coast. Mar. Pollut. Bull. 56, 359-363.

Haraguchi, K., Hisamichi, Y., Kotaki, Y., Kato, Y., Endo, T., 2009. Halogenated bipyrroles and methoxylated tetrabromodiphenyl ethers in tiger shark (Galeocerdo cuvier) from the southern coast of Japan. Environ. Sci. Technol. 43, 2288-2294.

Heupel, M.R., Simpfendorfer, C., Collins, A.B., Tyminski, J.P., 2006. Residency and movement patterns of bonnethead sharks, Sphyrna tiburo, in a large Florida estuary. Environ. Biol. Fishes 76, 47-67.

Johnson, M.R., Snelson Jr, F.F., 1996. Reproductive life history of the Atlantic stingray, Dasyatis sabina (Pisces, Dasyatidae), in the freshwater St. Johns River, Florida. Bull. Mar. Sci. 59, 74-88.

Johnson-Restrepo, B., Kannan, K., Addink, R., Adams, D.H., 2005. Polybrominated diphenyl ethers and polychlorinated biphenyls in a marine foodweb of coasta Florida. Environ. Sci. Technol. 39, 8243-8250.

Kajiura, S.M., Tricas, T.C., 1996. Seasonal dynamics of dental sexual dimorphism in the Atlantic stingray Dasyatis Sabina. J. Exp. Biol. 199, 2297-2306.

Kannan, K., Maruya, K.A., Tanabe, S., 1997. Distribution and characterization of polychlorinated biphenyl congeners in soil and sediment from a Superfund site contaminated with Aroclor 1268. Environ. Sci. Technol. 31, 1483-1488.

Keller, J.M., Alava, J.J., Aleksa, K., Young, B., Kucklick, J.R., 2005. Spatial trends of polybrominated diphenyl ethers (PBDEs) in loggerhead sea turtle eggs and plasma. Organohalogen Compd. 67, 610-611.

Keller, J.M., Carlson, B., Swarthout, R., Alava, J.J., Moss, S., Stewart, K., Aleksa, K., Wilson, T.P., Kucklick, J.R., 2007. PBDE concentrations and congener profiles among different turtle species, locations and sample types. Sixth Internationa Symposium on Flame Retardants, BFR2007 Abstracts: Exposure 1 Food \& Environment, p. 40

Kelly, B.C., Ikonomou, M.G., Blair, J.D., Morin, A.E., FAPC, Gobas, 2007. Food webspecific biomagnification of persistent organic pollutants. Science 317, 236-239.

Kucklick, J., Schwacke, L., Wells, R., Hohn, A., Guichard, A., Yordy, J., Hansen, L., Zolman, E., Wilson, R., Litz, J., Nowacek, D., Rowles, T., Pugh, R., Balmer, B., Sinclair, C., Rosel, P., 2011. Bottlenose dolphins as indicators of persistent organic pollutants in the Western North Atlantic Ocean and Northern Gulf of Mexico. Environ. Sci. Technol. 45, 4270-4277.

Lerner, D.T., Björnsson, B.T., McCormick, S.D., 2007. Effects of aqueous exposure to polychlorinated biphenyls (Aroclor 1254) on physiology and behavior of smolt development of Atlantic salmon. Aquat. Toxicol. 81, 329-336.

Lessa, R.P., Almeida, Z., 1998. Feeding habits of the bonnethead shark, Sphyrna tiburo, from northern Brazil. Cybium 22, 383-394.

Matich, P., Heithaus, M.R., Layman, C.A., 2010. Size-based variation in intertissue comparisons of stable carbon and nitrogen isotopic signatures of bull sharks (Carcharhinus leucas) and tiger sharks (Galeocerdo cuvier). Can. J. Fish. Aquat. Sci. 67, 877-885.

Morrissey, J.F., Gruber, S.H., 1993. Habitat selection by juvenile lemon sharks, Negaprion brevirostris. Environ. Biol. Fishes 38, 311-319.

Muirhead, E.K., Skillman, A.D., Hook, S.E., Schultz, I.R., 2006. Oral exposure of PBDE47 in fish: toxicokinetics and reproductive effects in Japanese medaka (Oryzias latipes) and fathead minnows (Pimephales promelas). Environ. Sci. Technol. 40, 523-528.

Nakayama, K., Oshima, Y., 2008. Adverse effects of tributyltin on reproduction of Japanese medaka, Oryzias latipes. Coast. Mar. Sci. 32, 67-76.

Natanson, L.J., Adams, D.H., Winton, M.V., Maurer, J.R., 2014. Age and growth of the bull shark in the Western North Atlantic Ocean. Trans. Am. Fish. Soc. 143 (3), 732-743.

Nirmala, K., Oshima, Y., Lee, R., Imada, N., Honjo, T., Kobayashi, K., 1999. Transgenerational toxicity of tributyltin and its combined effects with polychlorinated biphenyls on reproductive processes in Japanese medaka (Oryzias latipes). Environ. Toxicol. Chem. 18, 717-721.

Nomiyama, K., Uchiyama, Y., Horiuchi, S., Eguchi, A., Mizukawa, H., Hirata, S.H., Shinohara, R., Tanabe, S., 2011. Organohalogen compounds and their metabolites in the blood of Japanese amberjack (Seriola quinqueradiata) and scalloped hammerhead shark (Sphyrna lewini) from Japanese coastal waters. Chemosphere 85, 315-321.

Olin, J.A., Hussey, N.E., Grgicak-Mannion, A., Fritts, M.W., Wintner, S.P., Fisk, A.T., 2013. Variable $\delta^{15} \mathrm{~N}$ diet-tissue discrimination factors among sharks: implications for trophic position, diet and food web models. PLoS One 8 (10), e77567. http://dx.doi.org/10.1371/journal.pone.0077567.

Olin, J.A., Beaudry, M., Fisk, A.T., Paterson, G., 2014. Age-related polychlorinated biphenyl dynamics in immature bull sharks (Carcharhinus leucas). Environ. Toxicol. Chem. , http://dx.doi.org/10.1002/etc.2402.
Pulster, E.L., Maruya, K.A., 2008. Geographic specificity of Aroclor 1268 in bottlenose dolphins (Tursiops truncatus) frequenting the Turtle/Brunswick River Estuary, Georgia (USA). Sci. Total Environ. 393, 367-375.

Reyier, E.A., Adams, D.H., Lowers, R.H., 2008. First evidence of a high density nursery ground for the lemon shark, Negaprion brevirostris, near Cape Canaveral, Florida. Biol. Sci. 71, 134-148.

Ross, P.S., 2000. Marine mammals as sentinels in ecological risk assessment. Hum. Ecol. Risk Assess. 6, 1-18.

Ross, P.S., De Swart, R.L., Timmerman, H.H., Reijnders, P.J.H., Vos, J.G., Van Loveren, H., Osterhaus, A.D.M.E., 1996. Suppression of natural killer cell activity in harbour seals (Phoca vitulina) fed Baltic Sea herring. Aquat. Toxicol. 34, 71-84.

Schlenk, D., Sapozhnikova, Y., Cliff, G., 2005. Incidence of organochlorine pesticides in muscle and liver tissues of South African great white sharks Carcharodon carcharias. Mar. Pollut. Bull. 50, 208-211.

Schwacke, L.H., Zolman, E.S., Balmer, B.C., De Guise, S., George, R.C., Hoguet, J., Hohn, A.A., Kucklick, J.R., Lamb, S., Levin, M., Litz, J.A., McFee, W.E., Place, N.J., Townsend, F.I., Wells, R.S., Rowles, T.K., 2012. Anaemia, hypothyroidism and immune suppression associated with polychlorinated biphenyl exposure in bottlenose dolphins (Tursiops truncatus). Proc. R. Soc. B: Biol. Sci. 279, 48-57.

Serrano, R., Fernandez, M., Rabanal, R., Hernadez, M., Gonzalez, M.J., 2000. Congener-specific determination of polychlorinated biphenyls in shark and grouper livers from the Northwest African Atlantic Ocean. Archives of Environmental Contamination and Toxicology 38, 217-224.

Snelson, F.F., Mulligan, T.J., Williams, S.E., 1984. Food habits, occurrence, and population structure of the bull shark, Carcharhinus leucas, in Florida coastal lagoons. Bull. Mar. Sci. 34, 71-80.

Snelson, F.F., Williams-Hooper, S.E., Schmid, T.H., 1988. Reproduction and ecology of the Atlantic stingray, Dasyatis sabina, in Florida coastal lagoons. Copeia 3 , 729-739.

Sonne, C., Gustavson, K., Rigét, F.F., Dietz, R., Birkved, M., Letcher, R.J., Bossi, R., Vorkamp, K., Born, E.W., Petersen, G., 2009. Reproductive performance in East Greenland polar bears (Ursus maritimus) may be affected by organohalogen contaminants as shown by physiologically-based pharmacokinetic (PBPK) modelling. Chemosphere 77, 1558-1568.

Stapleton, H.M., Letcher, R.J., Baker, J.E., 2004. Debromination of polybrominated diphenyl ether congeners BDE 99 and BDE 183 in the intestinal tract of the common carp (Cyprinus carpio). Environ. Sci. Technol. 38, 1054-1061.

Storelli, M.M., Marcotrigiano, G.O., 2001. Persistent organochlorine residues and toxic evaluation of polychlorinated biphenyls in sharks from the Mediterranean Sea (Italy). Mar. Pollut. Bull. 42, 1323-1329.

Storelli, M.M., Storelli, A., Marcotrigiano, G.O., 2005. Concentrations and hazard assessment of polychlorinated biphenyls and organochlorine pesticides in shark liver from the Mediterranean Sea. Mar. Pollut. Bull. 50, 850-855.

Strid, A., Athanassiadis, I., Athanasiadou, M., Svavarsson, J., Papke, O., Bergman, A. 2010. Neutral and phenolic brominated organic compounds of natural and anthropogenic origin in northeast Atlantic Greenland shark (Somniosus microcephalus). Environ. Toxicol. Chem. 29, 2653-2659.

Thorson, T.B. 1971. Movements of bull sharks, Carcharhinus leucas, between the Caribbean Sea and Lake Nicaragua demonstrated by tagging. Copeia, 336-338.

Thomerson, J.E., Thorson, T.B., Hempel, R.L., 1977. The bull shark, Carcharhinus leucas, from the upper Mississippi River near Alton, Illinois. Copeia, 166-168.

Tillett, B.J., Meekan, M.G., Field, I.C., Thorburn, D.C., Ovenden, J.R., 2012. Evidence for reproductive philopatry in the bull shark Carcharhinus leucas. J. Fish Biol. 80, 2140-2158.

Trefry, J.H., Windsor Jr, J.W., Trocine, R.P., 2008. Toxic substances in the Indian River Lagoon: Results from the 2006/7 survey. the St. Johns River Water Management District, Palatka, FL (Final Report to St. Johns River Water Management District. Available from).

Trefry, J.H., Trocine, R.P., 2011. Metals in sediments and clams from the Indian River Lagoon, Florida: 2006-7 versus 1992. Fla. Sci., 74; p. 43.

Trocine, R.P., Trefry, J.H., 1993. Toxic substances survey for the Indian River Lagoon System, the St. Johns River Water Management District, Palatka, FL (Final Report to St. Johns River Water Management District. Available from the St. Johns River Water Management District, Palatka, FL.).

Vigano, L., Arillo, A., Falugi, C., Melodia, F., Polesello, S., 2001. Biomarkers of exposure and effect in flounder (Platichthys flesus) exposed to sediments of the Adriatic Sea. Mar. Pollut. Bull. 42, 887-894.

Weijs, L., Dirtu, A.C., Das, K., Gheorghe, A., Reijnders, P.J.H., Neels, H., Blust, R., Covaci, A. 2009. Inter-species differences for polychlorinated biphenyls and polybrominated diphenyl ethers in marine top predators from the southern North Sea: Part 1. Accumulation patterns in harbour seals and harbour porpoises. Environ. Pollut. 157, 437-444. 